\title{
THE APPLICATION OF RISK BASED BANK RATING ON BANKRUPTCY PREDICTION OF BANKS IN INDONESIA
}

\author{
Evi Sistiyarini ${ }^{1}$, Sudjarno Eko Supriyono ${ }^{2}$ \\ ${ }^{1}$ Bachelor of Manajement Department, STIE Perbanas Surabaya \\ ${ }^{2}$ Department of Diploma 3 Finance and Banking STIE Perbanas Surabaya \\ Nginden Semolo 34-36 Surabaya, 60118, Indonesia
}

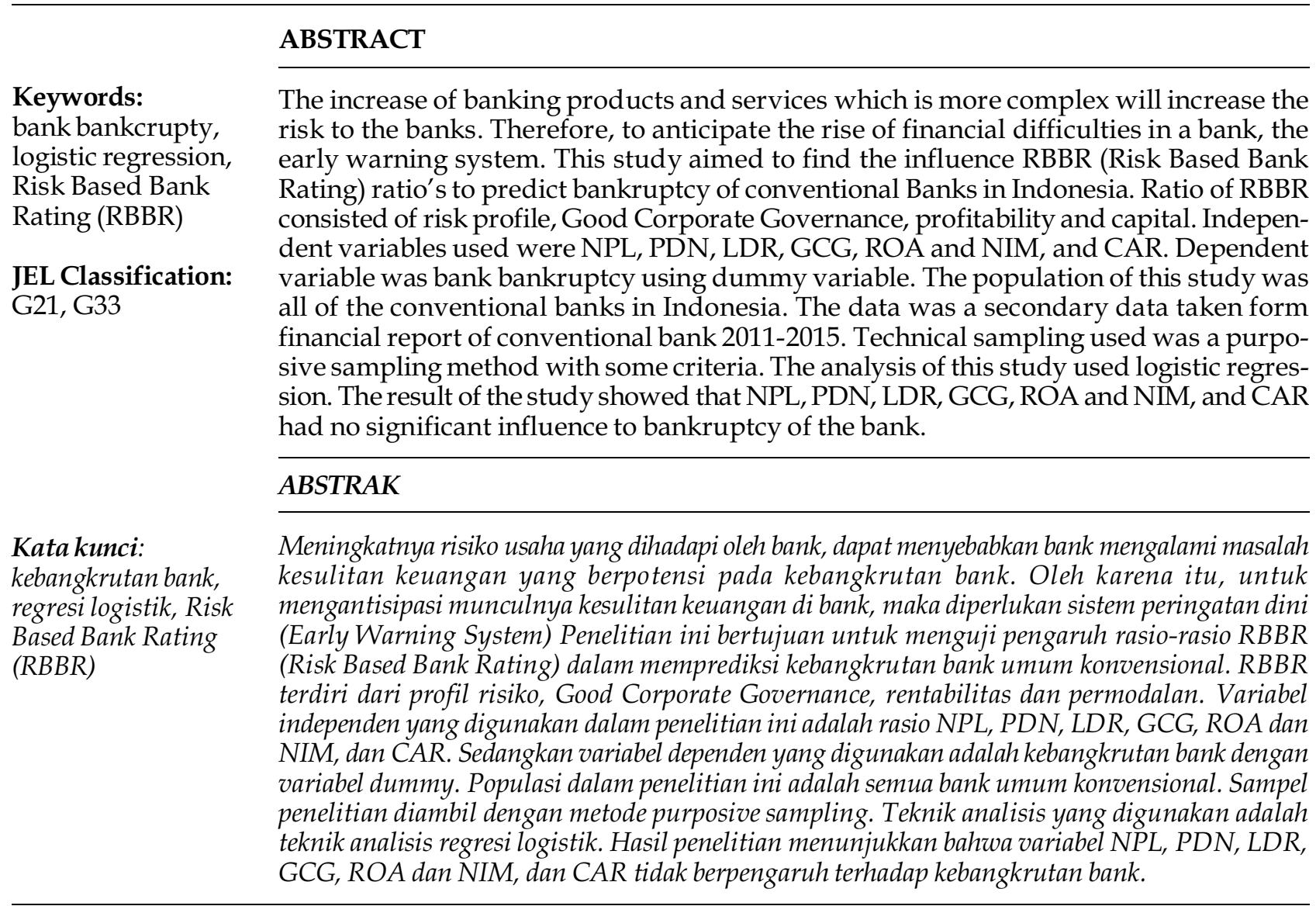


The development of the banking industry in Indonesia continues to increase in terms of assets, institutions, growth of funds and funds distribution. Data on Banking Annual Report 2015 showed that national banks in 2015 experienced rapid growth with asset growth of $9.21 \%$, credit growth of $10.44 \%$ and growth of third party funds of $7.26 \%$.

The increase of banking products and services which is more complex will increase the risk to the banks. The increase of business risk faced by the banks can cause financial difficulties banks which has potential problems in bankruptcy. The failure experienced by a bank can have effect on non-financial companies and may influence the supply of funds in credit markets (Wibowo \& Ham, 2016). Therefore, to anticipate the rise of financial difficulties in a bank, the early warning system to financial problems that could threaten the banking operations is needed. The earlier the bank detects banking conditions, the faster the bank does anticipatory steps so that financial difficulties can be resolved soon. Early warning system can be developed by logic multinomial model (Bussiere \& Fratzscher, 2006).

Bankruptcy is defined as a failure of the company in carrying out operational activities. Bankruptcy case of bank ever happened in 1997 at the time of economic crisis. Based on data from Bank Indonesia it was known that there were 16 banks that had been closed by the government at that time. In 2008, bankruptcy of banks also took place in Indonesia, namely the Century Bank. Century Bank financial crisis was the impact of the global crisis experienced by the banking world. The crisis experienced by Bank Century caused customers to withdraw their funds on a large scale.

In 2011, Bank Indonesia issued regulation, namely Bank Indonesia Regulation (Peraturan Bank Indonesia) No.13/1/ PBI / 2011 about health assessment of commercial banks. Based on the regulation, banks were required to assess the bank health level individually using risk approach (RiskBased Bank Rating). The assessment consisted of risk profile factor (risk profit), GCG (Good Corporate Governance) factor, profitability factor and capital factor. The risk profile used in this research is credit risk, market risk and liquidity risk.

Credit risk is a risk faced by the bank due to the failure of the debtor in fulfilling the obligations to the bank (Rustam, 2013). Credit risk can be measured using NPL (Non-Performing Loan) ratio. NPL ratio is the ratio of the occurrence of loans having problems in a bank. Haryetti (2010) states that the financial ratio having a dominant influence on financial difficulties bank is NPL. Rokhim \& Yanti (2014) mention that banks will give credit if the economic growth improves. This will have an impact on the declining of NPL value. The research result conducted by Sumantri \& Jurnali (2010) and Nugroho (2012) proved that NPL had no effect on bank insolvency. Zaghdoudi (2013), Hidayati (2015) indicated that NPL had a positive and insignificant influence on bank bankruptcy potential. This is contrary to research conducted by Hilmy et al. (2013) that proved NPL had a significant negative effect on bank bankruptcy in Malaysia. Prasidha \& Wahyudi (2015) had also proved that NPL could be used to predict bank troubled conditions.

Market risk represents is risk on balance sheet position and administrative account including derivative transaction caused by market price change (Rustam, 2013). Bank market risk can be measured using Net Foreign Exchange Position (PDN) ratio toward capital. Research conducted by Prasidha \& Wahyudi (2015) had proven that PDN could be used to predict the troubled condition of the bank.

Liquidity risk is the risk faced by the bank being unable to pay off short-term liabilities (Rustam, 2013). Liquidity risk in this study was measured using the LDR (Loan to Deposit Ratio) namely the ratio of credit given to third party 


\section{Jurnal Keuangan dan Perbankan | PERBANKAN}

Vol. 21, No. 2, April 2017: 302-311

funding source. Prajitno (2009) has proven that liquidity ratio is the best ratio in determining bankruptcy of a bank. Sumantri \& Jurnalli (2010) and Nugroho (2012) have found that LDR has significant negative effect on bank bankruptcy. This is not in line with Hidayati's research (2015) that has proven that LDR has significant positive effect on the bank's bankruptcy. Prasidha \& Wahyudi (2015) give different results that the LDR cannot be used to predict the occurrence of bank troubled conditions.

The definition of Good Corporate Governance according to PBI number 11/33/PBI/2009 is bank governance based on transparency, accountability, responsibility, professionalism, and fairness. Kusmayadi (2012) stated that good implementation of GCG will be able to give a good performance implication for the bank. Baklouti et al. (2016) found that GCG does not affect the financial difficulties in banks.

Profitability is the bank's ability to generate profits. The profitability ratio used in this study was ROA (Return on Assets) and NIM (Net Interest Margin). Zaghdoudi (2013) and Baklouti et al (2016) have shown that Profitability has a negative effect on a bank failure. Nugroho's research (2012) proves different result namely ROA has no effect on bankruptcy of banks. This is contrary to Sumantri \& \& Jurnali (2010) and Prasidha \& Wahyudi (2015) who prove that ROA has positive effect on the condition of troubled banks. Research conducted by Prasidha \& Wahyudi (2015) indicates that NIM cannot be used to predict the troubled condition of banks. Nugroho (2012) is in line with the research. This is in contrast with Sumantri \& Jurnali (2010) who actually found that ROA has a significant positive effect on bank bankruptcy.

Capitalization is one of the important factors for banks to develop business and accommodate the risk of loss (Rustam, 2013). Bank capital can be measured using CAR (Capital Adequacy Ratio). CAR ratio is the capital adequacy ratio which is owned by banks. Research conducted by Hidayati (2015) has shown that the CAR has negative and not significant to the bank's collapse. Prasidha Wahyudi (2015) also provide evidence that CAR cannot be used to predict bank troubled conditions. Sumantri \& Jurnali (2010) and Nugroho (2012) also give the same result.

This study aimed to analyze the effect of RBBR ratios on bank bankruptcy prediction. Several studies of bank bankruptcy prediction model have been done before and give different results so that they become research gap for this study. Therefore, further research on the analysis of RBBR implementation on bankruptcy prediction of conventional commercial banks in Indonesia is needed.

\section{HYPOTHESES DEVELOPMENT}

NPL positively affects the bankruptcy potential of a bank. NPL reflects the troubled condition of a bank. The higher NPL of a bank indicates that the number of nonperforming loans has increased bigger than the total credit. The increasing number of nonperforming loans indicates the higher the difficulty of loan payment by debtors. The provision of Bank Indonesia mentions that a healthy bank NPL ratio is below $5 \%$. The high NPL ratio of a bank can have an impact on rising credit risk. The higher the credit risk faced by the bank is, the higher the bankruptcy potential of a bank is. $\mathrm{H}_{1}$ : NPL has a significant positive effect on bankruptcy prediction of conventional commercial banks in Indonesia.

The PDN ratio to capital positively affects the bankruptcy potential of banks. The higher the PDN ratio to capital is, the higher the market risk experienced by banks is due to changes in market prices in the form of exchange rates. The high market risk has an impact on the increasing potential bankruptcy of banks. 
$\mathrm{H}_{2}$ : PDN ratio to capital has a significant positive effect to potential bankruptcy of conventional commercial banks in Indonesia.

LDR reflects the amount of credit distributed to debtors from third party fund sources in the bank. The higher bank LDR ratio indicates that the bank's ability to meet short-term obligations is good. The higher the bank's ability to meet shortterm obligations is, the lower the risk of bank liquidity is. The lower the risk of bank liquidity is, the lower the bankruptcy potential of the bank is. $\mathrm{H}_{3}$ : LDR has significant negative effect on the potential bankruptcy of conventional commercial banks in Indonesia

GCG negatively affects the bankruptcy potential of banks. The higher the GCG is, the better the governance of the bank is. The higher the GCG is, the lower the bankruptcy potential of the bank is. $\mathrm{H}_{4}$ : GCG has a negative effect on the potential bankruptcy of conventional commercial bankskonvensional di Indonesi in Indonesia.

ROA negatively affects the bankruptcy potential of banks. ROA reflects the bank's ability to generate profits from its assets. The higher the ROA is, the better the bank's ability to generate profits. It shows that bank profitability is also getting better. The higher the profitability generated by the bank is, the lower the bankruptcy potential of the bank is. Sumantri \& Jurnali (2010) provide the evidence that ROA has a significant effect on bankruptcy.

$\mathrm{H}_{5}$ : ROA has a significant negative effect on the potential bankruptcy of conventional commercial banks in Indonesia.

NIM negatively affects the bankruptcy potential of banks. NIM reflects the bank's ability to generate net interest income from the average productive assets. The higher the NIM ratio is, the higher the bank's ability to generate interest income is. The higher the bank's income is, the lower the bankruptcy potential of the banks is.

$\mathrm{H}_{6}$ : NIM has a significant negative effect on the potential bankruptcy of conventional commercial banks konvensional di Indonesia. in Indonesia.

CAR negatively affects the bankruptcy potential of banks. CAR reflects the capital adequacy held by a bank. The higher the bank's CAR is, the higher the capital it owns. Adequate capital for banks can be used to cover the risks. Therefore, the higher the bank's capital is, the lower the bankruptcy potential of the bank is.

$\mathrm{H}_{7}$ : CAR has a significant negative effect on the potential bankruptcy of conventional commercial banks in Indonesia.

\section{METHOD}

This research was a quantitative research with verificative research design that served to test the truth of another research.

The population of this research was all commercial banks in Indonesia. The sampling technique in this study used purposive sampling with the following criteria: (1) conventional banks that presented the financial statements in succession in the period of 2011-2015. (2) Commercial banks that involved in the category of 10 Commercial Banks of Business Activities (BUKU) II and BUKU III which had the largest assets. Based on these criteria, 20 banks as samples were obtained.

The data source used in this research was secondary data sources derived from conventional commercial bank's financial statements in the period of 2011-2015. Data collection techniques used in this study was a documentation technique that 


\section{Jurnal Keuangan dan Perbankan | PERBANKAN}

Vol. 21, No. 2, April 2017: 302-311

was by documenting the financial statements data that had been collected.

Operationalization of research variables can be seen in Table 1.

The analysis technique used in this research was logistic regression analysis. Logistic regression equation can be stated as follows (Ghozali, 2006).

Ln [odds (S | X1, X2, Xk)]=B0-b $1 \times 1+$ b 2 X $2+b$ $3 \times 3+b 4+b 4 \times 5 \times 5+b 6 \times 6+b 7 \times 7+e$

Odds $(S \mid X 1, X 2, X k)=p / 1-p$

Information:

$\mathrm{P}=$ bankruptcy probability of bank

$\mathrm{X}=$ independent variable
The analysis steps in logistic regression are as follows (Ghozali, 2006):

\section{Assessing Model Fit}

Hypotheses to assess the overall model fit are:

Ho $=$ Model hypothesized is fit with data

$\mathrm{Ha}=$ Model hypothesized is not fit with the data

\section{Parameter Estimation and Interpretation}

Maximum likelihood estimation of the model parameters can be viewed on the display output of the variable in the equation.

Table 1. Operationalization and Measurement of Research Variables

\begin{tabular}{|c|c|c|}
\hline $\begin{array}{l}\text { Research } \\
\text { Variable }\end{array}$ & Definition of Variables & Variable Measurement \\
\hline Bankruptcy (Y) & A bankruptcy condition of the bank & $\begin{array}{l}\text { Dummy variable with terms } Y=0 \text { for } \\
\text { banks that are not bankrupt, and } Y=1 \\
\text { for bankrupt banks. }\end{array}$ \\
\hline NPL (X1) & $\begin{array}{l}\text { Ratio reflecting the condition of problematic loans } \\
\text { experienced by conventional banks (SEBI No. 13/24 / } \\
\text { DPNP) }\end{array}$ & NPL $=\frac{\text { Non Performing Loan }}{\text { Total Credit }}$ \\
\hline $\begin{array}{l}\text { PDN Ratio to } \\
\text { Capital }(X 2)\end{array}$ & $\begin{array}{l}\text { The ratio reflecting the net foreign exchange position } \\
\text { on capital at conventional commercial banks }\end{array}$ & PND Ratio on Capital $=\frac{\text { PND }}{\text { Capital }}$ \\
\hline LDR (X3) & $\begin{array}{l}\text { Comparison ratio between loans provided and third } \\
\text { party funds on conventional commercial banks } \\
\text { (Taswan, 2010) }\end{array}$ & $\mathrm{LDR}=\frac{\text { Total Credit }}{\mathrm{DPK}}$ \\
\hline GCG (X4) & $\begin{array}{l}\text { Good governance conditions in conventional } \\
\text { commercial banks }\end{array}$ & $\begin{array}{l}\text { The composite value on GCG report of } \\
\text { conventional commercial banks } \\
\text { Profit before tax }\end{array}$ \\
\hline ROA (X5) & $\begin{array}{l}\text { Ratio reflecting the ability of conventional commercial } \\
\text { banks to generate profits (SEBI No.13/24/ DPNP) }\end{array}$ & $\mathrm{ROA}=\overline{\text { Average of total asset }}$ \\
\hline NIM (X6) & $\begin{array}{l}\text { The ratio used to determine the ability of productive } \\
\text { assets in generating profit (SEBI No. 13/24 / DPNP) }\end{array}$ & $\mathrm{NIM}=\frac{\text { Nett Interest Income }}{\text { Average of Product Asset }}$ \\
\hline CAR (X7) & $\begin{array}{l}\text { The ratio used to measure the capital of conventional } \\
\text { commercial banks }\end{array}$ & $\mathrm{CAR}=\frac{\text { Capital }}{\text { ATMR }}$ \\
\hline
\end{tabular}


Table 2. Descriptive Statistics Analysis Result

\begin{tabular}{lccrrr}
\hline & N & Minimum & Maximum & Mean & Std. Deviation \\
\hline X1 & 100 & .00 & 17.83 & 2.3270 & 2.97773 \\
X2 & 100 & .00 & 14.15 & 2.1914 & 2.71818 \\
X3 & 100 & 52.39 & 141.61 & 88.8030 & 13.45024 \\
X4 & 100 & 1.00 & 3.67 & 1.9242 & .45229 \\
X5 & 100 & -1.64 & 17.20 & 2.1878 & 2.87284 \\
X6 & 100 & 2.37 & 13.12 & 5.2802 & 2.20857 \\
X7 & 100 & 10.12 & 45.75 & 17.4443 & 5.68375 \\
Valid N & 100 & & & & \\
(listwise) & & & & \\
\hline
\end{tabular}

\section{RESULTS}

\section{Descriptive Statistics Analysis Result}

The following is the result of descriptive statistical analysis which can be seen in Table 2 .

Based on data in Table 2, it was known that NPL minimum value was $0.00 \%$ experienced by PT Bank Danamon Indonesia Tbk in 2011 while the maximum value experienced by PT Bank MNC International Tbk was $17.83 \%$. It showed that there were still banks that had a ratio of nonperforming loans which were quite high. It was not in accordance with the provisions of Bank Indonesia stating that a healthy bank was a bank that the NPL ratio was $<5 \%$.

The PDN ratio had a minimum value of $0 \%$ experienced by PT Bank Tabungan Pensiunan Nasional Tbk while the maximum value was $14.15 \%$ by PT Bank KEB Hana Indonesia Tbk. It indicated that the banks studied had met the provisions of Bank Indonesia that PDN maximum value was $20 \%$. LDR ratio had a minimum value of 52.39\%, namely PT Bank Mega Tbk in 2012 while the maximum value was $141.61 \%$ by PT Bank KEB Hanas Tbk. The data showed that there were banks that distributed loans in relatively large numbers compared to third parties fund amount and vice versa.

GCG ratio which had a minimum value of 1 was by PT Bank Maybank Tbk in 2012 while the maximum value of 3.67 was by PT Bank Windu
Kentjana Tbk in 2012. ROA ratio which had a minimum value of $-1.64 \%$ was PT Bank MNC International, Tbk in 2011 and a maximum value of $17.2 \%$ was by PT Bank Danamon Indonesia Tbk in 2011. It indicated that there were banks that suffered losses during the study period. NIM ratio which had a minimum value of $2.37 \%$ was by PT Bank ICBC Tbk in 2012 and a maximum value of $13.12 \%$ was by PT Bank Tabungan Pensiunan Nasional Tbk in 2012. CAR ratio which had a minimum value of $10.12 \%$ was PT Bank MNC Tbk in 2011 and a maximum value of $45.75 \%$ was by PT Bank QNB Indonesia Tbk. It indicated that the banks had strong capital and in accordance with provisions of Bank Indonesia namely at least $8 \%$.

\section{Fit Model Test}

Fit model test result from Hosmer and Lomeshow Test can be seen in Table 3.

Table 3. Hasil Hosmer and Lomeshow Test Hosmer and Lomeshow Test Result (Fit Model Test)

\begin{tabular}{llll}
\hline Step & Chi-square & Df & Sig. \\
\hline 1 & .000 & 8 & 1.000 \\
\hline
\end{tabular}

Based on the results of Hosmer and Lomeshow Test in Table 3, it was known that the significance value was greater than 0.05 so it could be concluded that the model was acceptable because it matched the observation data. 


\section{Jurnal Keuangan dan Perbankan | PERBANKAN}

Vol. 21, No. 2, April 2017: 302- 311

\section{Hypothesis Test Result}

Hypothesis test result from logistic regression can be seen in Table 4 .

Based on the hypothesis testing result in Table 4 it was known that NPL ratio was in sign positive, with a coefficient of 4.941 . The significance value of NPL ratio was 0.999 above 0.05 . It could be concluded that NPL did not affect the bank's collapse. The increase or decrease in NPL did not have impact on bankruptcy of banks. It meant that the credit risk did not have effect on bank's collapse.

$\mathrm{R}$ asio PDN ratio to capital marked positive with coefficient 0.487 , the significance value obtained was 1,000 and the value was above 0.05 . So it can be concluded that PDN variable did not have effect on bankruptcy of the bank. Increase or decrease of PDN to capital did not have effect on bankruptcy of bank. Market risk did not have effect on bankruptcy of the bank.

LDR had a regression coefficient -0.042. Significance value was 1.000 above 0.05 . Based on the results of the test it could be concluded that LDR did not have effect on bankruptcy of the bank. The increase or decrease of LDR did not have impact on the bankruptcy of banks. Liquidity risk did not have effect on the bank's collapse

GCG ratio had a regression coefficient value of -4.493 and a significant value of 1.000 above 0.05 . Thus, it can be concluded that GCG did not have effect on bankruptcy of the bank. Increase or decrease of GCG did not affect bankruptcy of banks.

ROA had a coefficient value of 0.814 . The significance value was 1.000 above 0.05 . It could be concluded that ROA did not have effect on bankruptcy of the bank. Increase or decrease of ROA did not affect bankruptcy of the bank.

NIM had a coefficient value of 1.870 with a significance value of 1,000 above 0.05 . It could be concluded that NIM did not have effect on bankruptcy of the bank. The increase or decrease of NIM did not have impact on bankruptcy of the bank. The bank's profitability did not have effect on bankruptcy of the bank.

CAR had a coefficient value of -0.195 and significance value of 1.000 above 0.05 . It indicated that CAR did not affect the bank's collapse. The increase or decrease of CAR did not have impact on bankruptcy of banks. Capital did not have effect on bankruptcy of banks.

\section{DISCUSSION}

Theoretically, credit risk had a positive impact on bank bankruptcy. One measurements of credit risk was using NPL ratio. Theoretically, the higher NPL also had a positive effect on the bankruptcy of the bank. The higher the NPL was, the higher the credit risk faced by the bank, the higher the bankruptcy potential of the bank was. However, this study showed that NPL did not have

Table 4. Hypothesis Test Results Variables in the Equation

\begin{tabular}{llrrrrrr}
\hline & \multicolumn{1}{c}{ B } & \multicolumn{1}{c}{ SE } & Wald & Df & \multicolumn{1}{c}{ Sig. } & Exp (B) \\
\hline Step 1 & X1 & 4.941 & 5007.304 & .000 & 1 & .999 & 139.877 \\
(a) & X2 & .487 & 2652.833 & .000 & 1 & 1.000 & 1.627 \\
& X3 & -.042 & 362.052 & .000 & 1 & 1.000 & .959 \\
& X4 & -4.493 & 30558.291 & .000 & 1 & 1.000 & .011 \\
& X5 & -.814 & 10243.026 & .000 & 1 & 1.000 & .443 \\
& X6 & 1.870 & 5453.319 & .000 & 1 & 1.000 & .487 \\
& X7 & -.195 & 1913.508 & .000 & 1 & 1.000 & .823 \\
& Constant & -31.770 & 92171.087 & .000 & 1 & 1.000 & .000 \\
\hline
\end{tabular}




\section{The Application of Risk Based Bank Rating on Bankruptcy Prediction of Banks in Indonesia}

Evi Sistiyarini \& Sudjarno Eko Supriyono

effect on bankruptcy of banks. Bank Indonesia had a provision of NPL for commercial banks namely below $5 \%$. In study period, the average value of NPL of conventional commercial banks was already below 5\%, although there was 1 bank that had a quite high NPL (above 10\%). It meant that conventional commercial banks had implemented provisions that had been made by Bank Indonesia. The research result was in line with research conducted by (Sumantri \& Jurnali 2010; Nugroho, 2012) that NPL did not affect the bank bankruptcy. However, the result of this study was not in line with the research of Hilmy (2013), Zaghdoudi (2013), Hidayati (2015), Prasidha \& Wahyudi (2015).

Theoretically market risk had a positive influence on the bankruptcy of banks. One measurements of market risk was using PDN ratio to capital. The higher the PDN was, the higher the market risk of the bank was, and the higher the market risk was the higher the bankruptcy of the bank was. The results showed that PDN ratio to capital did not have effect on bankruptcy of banks. The results did not support the theory. Bank Indonesia's provision on PDN was maximum 20\%. During the study period, conventional commercial banks in Indonesia had met the PDN requirement with a ratio below $20 \%$. This study did not support the research conducted by Prasidha \& Wahyudi (2015) who found that PDN could be used to predict the bank's troubled condition.

Theoretically, liquidity risk had a positive influence on the bankruptcy of banks. Bank liquidity risk could be measured using LDR. LDR had a negative effect on the bankruptcy of banks. The lower the LDR of the bank was, the higher the liquidity risk faced by the bank. The higher the risk of liquidity was, the higher the bankruptcy of the bank was. The result of this study indicated that LDR did not have effect on bankruptcy of banks. So this study did not support the theory. This study supported Prasidha \& Wahyudi's (2015) study which found that LDR could not be used to predict the occurrence of troubled conditions of banks. This research was not in line with the researches done by Prajitno (2009), Sumantri \& Jurnali (2010), Nugroho (2012) and Hidayati (2015).

Theoretically, GCG had a negative effect on the bankruptcy of banks. The better the governance of the bank was, the lower the bankruptcy potential of the bank was. However, this study proved that GCG did not have effect on bankruptcy of banks. This study did not support the theory. It indicated that during the research period conventional banks had made good governance efforts. This research result was consistent with the research conducted by Baklouti et al. (2016), which proved that GCG did not affect the bank's financial difficulties.

Theoretically, bank profitability measured by ROA and NIM had negative effect on bankruptcy of banks. The higher the bank's ability to generate profits was, the lower the bankruptcy potential of the bank was. The result of this study indicated that ROA did not have effect on bankruptcy of banks. This study did not support the theory. During the study period, conventional banks had an average value of $2.18 \%$. It meant that the bank's ability to produce was good enough. The result of this study supported Nugroho's research (2012) that said ROA did not have effect on bankruptcy bank. However, this study was not in line with the researches conducted by Sumantri \& Jurnali (2010), Zaghdoudi (2013), and Baklouti (2016).

The result of this study proved that NIM did not affect bankruptcy bank. During the study period, conventional commercial banks had an average of $5.28 \%$. It indicated that the bank's ability to generate interest income was good enough. The result of this study did not support the theory. However, this study supported the research conducted by Nugroho (2012) and Prasidha \& Wahyudi (2015) proving that NIM could not be 


\section{Jurnal Keuangan dan Perbankan | PERBANKAN}

Vol. 21, No. 2, April 2017: 302- 311

used to predict the bank's troubled condition. This research did not support the research of Sumantri \& Jurnali (2010).

Theoretically, capital affected negatively the bankruptcy of banks. The capital ratio could be measured by CAR. The higher the CAR was, the stronger the bank's capital was. The stronger the bank's capital was, the lower the bankruptcy potential of the bank was. The results of this study did not support the theory. This study had proved that CAR did not affect bankruptcy of banks. Bank Indonesia had determined that CAR ratio for commercial banks was at least $8 \%$. During the study period, conventional commercial banks had an average of $17.4 \%$ far above $8 \%$. It indicated that the bank had complied with the provision of Bank Indonesia so it could be said that conventional commercial banks already had very strong capital. This study supported researches conducted by Sumantri \& Jurnali (2010), Nugroho (2012), Hidayati (2015), and Prasidha \& Wahyudi (2015)

\section{CONCLUSION AND SUGGESTION}

\section{Conclusion}

This study aimed to examine the effect of RBBR (Risk Based Bank Rating) ratios in predicting bankruptcy of conventional banks. The results of this study show that NPL, PDN, LDR, GCG, ROA, NIM, and CAR variables do not affect bankruptcy of banks. It indicates that the magnitude of risk faced by conventional commercial banks (credit risk, market risk, liquidity risk, profitability, and capital) does not affect bankruptcy of banks. During the study period, conventional commercial banks were able to manage/anticipate the risk well. It was indicated by the independent variables studied which had an average value which was in accordance with the provisions made by Bank Indonesia in spite of an increase or decrease the value of the variable.

\section{Suggestion}

Conventional commercial banks should continue to pay attention to the risks that can be experienced by banks such as credit risk, market risk and liquidity risk. Although the research results showed there was no effect between RBBR variable and bankruptcy of bank, the risk management is still needed. Early handling of possible risks faced by banks will be able to make banks resistant to the threat of bankruptcy that could happen.

For further researchers, they should be able to do more researches on the application of RBBR variables in different types of banks and different bank groups such as Islamic banks, all foreign exchange banks, and BPR. In addition, researchers can also add other variables not examined in this study as variable of inflation, the type of compliance risk, or the risk of reputation. Researchers can also add to the number of the study period.

\section{REFERENCES}

Baklouti, N., Gautier, F \& Affes, H. 2016. Corporate Governance and Financial Distress of European Commercial Banks. Journal of Business Studies Quarterly, 7(3): 75-96.

Bussiere, M. \& Fratzscher, M. 2006. Towards ANew Early Warning System of Financial Crisis, Journal of International Money and Finance, 25(1): 953-973.

Ghozali. 2006. Aplikasi Analisis Multivariate dengan Program SPSS. Yogyakarta: Badan Penerbit Universitas Diponegoro.

Haryetti. 2010. Analisis Financial Distress untuk Memprediksi Risiko Kebangkrutan Perusahan (Studi pada Industri Perbankan di BEI). Jurnal Ekonomi, 18(2).

Hidayati, L.N. 2015. Pengaruh Kecukupan Modal (CAR), Pengelolaan Kredit (NPL) dan Likuiditas Bank (LDR) terhadap Probabilitas Kebangkrutan Bank (Studi pada Bank Umum Swasta devisa yang Tercatat di BEI Tahun 2009-2013). Jurnal Ilmu Manajemen, 12(1): 38-50. 


\section{The Application of Risk Based Bank Rating on Bankruptcy Prediction of Banks in Indonesia}

Evi Sistiyarini \& Sudjarno Eko Supriyono

Hilmy, H., Mohd, S \& Fahami, S. 2013. Factor Affecting Bankruptcy: The Case Of Malaysia. International Journal of Undergraduates Studies, 2(3): 4-8.

Kusmayadi, D. 2012. Determinasi Audit Internal dalam Mewujudkan Good Corporate Governance serta Implikasinya pada Kinerja Bank. Jurnal Keuangan dan Perbankan, 16(1): 147-156.

Nugroho, V. 2012. Pengaruh CAMEL dalam Memprediksi Kebangkrutan Bank, Jurnal Akuntansi, 14(1): 145161.

Peraturan Bank Indonesia No 13/1/PBI/2011 Tentang Penilaian Tingkat Kesehatan Bank Umum.

Prajitno,T. 2009. Model Kepailitan Bank Umum di Indonesia. Jurnal Trikonomika, 8(1): 14-21.

Prasidha, D.K \& Wahyudi, ST. 2015. Dampak Nilai Tukar dan Risk Based Bank Rating terhadap Prediksi Kondisi Perbankan Indonesia, QE Journal, 4(3):122142.

Rahmaniah, M \& Wibowo, H. 2015. Analisis Potensi Terjadinya Financial Distress pada Bank Umum Syariah (BUS) di Indonesia. Jurnal Ekonomi dan Perbankan Syariah, 3(1): 1-20.
Rokhim, R \& Yanti, M. 2014. Risiko NPL Kredit Bank Pembangunan Daerah sebagai Regional Champion, Jurnal Keuangan dan Perbankan, 18(1): 120129.

Rustam, B. 2013. Manajemen Risiko Perbankan Syariah di Indonesia. Salemba Empat. Jakarta.

Sumantri \& Jurnali, T. 2010. Manfaat Rasio Keuangan dalam Memprediksi Kepailitan Bank Nasional, Jurnal Bisnis dan Akuntansi. 12(1): 39-52.

Surat Edaran OJK No 13/24/DPNP Tentang Penilaian Tingkat Kesehatan Bank Umum.

Taswan. 2010. Manajemen Perbankan Konsep, Teknik, dan Aplikasi. Yogyakarta: UPP STIM YKPN. Bank Indonesia.

Wibowo, B \& Ham, W. 2016. Dampak Risiko Default Bank terhadap Risiko Sistemik Perbankan dan Risiko Sistematik Bursa Saham di Lima Negara ASEAN. Jurnal Keuangan dan Perbankan, 20(1): 6374

Zaghdoudi. 2013. Bank Failure Prediction with Logistic Regression. International Journal of Economics and Financial Issues, 3(2): 537-543. 